\title{
Lumen
}

Selected Proceedings from the Canadian Society for Eighteenth-Century Studies

\section{Polite Language and Female Social Agency in Frances Burney's Evelina}

\section{Kja Isaacson}

Volume 31, 2012

URI : https://id.erudit.org/iderudit/1013068ar

DOI : https://doi.org/10.7202/1013068ar

Aller au sommaire du numéro

Éditeur(s)

Canadian Society for Eighteenth-Century Studies / Société canadienne d'étude du dix-huitième siècle

ISSN

1209-3696 (imprimé)

1927-8284 (numérique)

Découvrir la revue

Citer cet article

Isaacson, K. (2012). Polite Language and Female Social Agency in Frances Burney's Evelina. Lumen, 31, 73-89. https://doi.org/10.7202/1013068ar

Copyright (c) Canadian Society for Eighteenth-Century Studies / Sociéte canadienne d'étude du dix-huitième siècle, 2012
Ce document est protégé par la loi sur le droit d'auteur. L'utilisation des services d’Érudit (y compris la reproduction) est assujettie à sa politique d'utilisation que vous pouvez consulter en ligne.

https://apropos.erudit.org/fr/usagers/politique-dutilisation/ 


\title{
Polite Language and Female Social Agency in Frances Burney's Evelina
}

\author{
KJA ISAACSON \\ University of Ottawa
}

Frances Burney's first novel, Evelina (1778), tells the story "of a young woman of obscure birth, but conspicuous beauty, for the first six months after her Entrance into the world." While Evelina's letters verify her individual eloquence from the beginning of Burney's novel, the heroine's mastery of the codes of social speech emerges only gradually. This paper will investigate the novel's representation of the reciprocal relation between linguistic and social development, exploring how Evelina's "entrance into the world" is imagined as an education in effective speech that in turn allows agency and social power. Criticism of Evelina often interprets the concluding marriage as submission to the patriarchal authority which so often limits and threatens Evelina over the course of the novel. From this perspective, Evelina's marriage marks the silencing of her authority through the end of her letter-writing, reinstating in the process not only male privilege, but also the social restrictions to which women in the eighteenth century were subject. This paper will offer an alternative reading: it will suggest that as Evelina becomes socially acclimatized and masters proper modes of speaking, she is able both to manifest her true intelligence and to defend herself when necessary. The end of Evelina's letterwriting marks the end of only one potential mode of communication; her newfound ability to use speech effectively, the novel implies, will

1. Frances Burney, Evelina, ed. Susan Kubica Howard (Peterborough: Broadview, 2000), 96. Evelina was originally published in three volumes. Further references are to this edition. 
prove a more influential and extensive means of conveying her intelligence and virtue than letter-writing.

The legitimizing marriage that concludes Evelina, passing Evelina from the hands of her guardian Mr. Villars to the protection of her husband Lord Orville, is often interpreted as a re-instatement of patriarchal authority. For instance, Judith Newton argues that "Evelina's destiny is to be protected, to marry, and her preparation for that future is to abdicate rather than to maintain power." ${ }^{2}$ Throughout the novel, Evelina struggles in society largely due to her lack of a legitimate (patriarchal) name, and, because of this lack of guardian or legal namesake, she must move through public spaces without male protection. ${ }^{3}$ While certain critics have found that Evelina "retrieves in the act of writing a richness of experience otherwise denied to her," ${ }^{\prime 4}$ the consensus is that Evelina's marriage - the legitimizing of her status by taking Orville's name - indicates her submission to a patriarchal code and the silencing of her limited authority with the end of her letterwriting. Certainly, female agency and authority were restricted in the eighteenth century, and Evelina's plot clearly functions within the confines of a patriarchal society. However, Burney's portrayal of her heroine's social development and her generous descriptions of polite and supportive male characters such as Villars and Orville suggest important variations in the ways of perceiving and treating women in this society.

Villars and Orville are often viewed as figures of patriarchal protection, but equally significantly, they admire Evelina's natural intelligence and virtue, acknowledge the validity of her opinions, and encourage her to "learn not only to judge but to act for [her]self." These two men are also exemplary in their use of a polite and sensible language that has a number of counterpoints, from Lord Merton's affected aristocratic drawl, through Sir Clement Willoughby's chivalric discourse, to Mrs. Selwyn's punitive satire. In Evelina, knowledge of

2. Judith Newton, “Evelina': Or, the History of a Young Lady's Entrance into the Marriage Market," Modern Language Studies 6, no.1 (1976): 53, http:// www.jstor.org/ stable/ 3194393 .

3. See Joanne Cutting-Gray, "Writing Innocence: Fanny Burney's Evelina," Tulsa Studies in Women's Literature 9.1 (1990): 44, http://www.jstor.org/stable/464180.

4. Cutting-Gray, 43.

5. Evelina, 279. 
proper social behavior and polite speech can help a woman to earn greater respect, agency, and social power. While Burney endorses a fairly conventional social politeness, she suggests that women may choose to submit to polite social conventions not only to satisfy patriarchal demands, but to further their own agency and social influence. In Evelina, this code of behaviour is most evident in the polite language that Burney endorses as the most admirable form of speech for both sexes. By recounting Evelina's education in polite speech, Burney seems to give priority to oral over verbal communication as a social medium, a priority which is only reinforced by the obvious problems with written communication between non-intimate characters (for instance, Willoughby's letter, forged under Orville's name).

When the novel begins, Evelina is "innocent as an angel, and artless as purity itself," and she strives, under Villars's encouragement, to retain her virtue and not let society erode her morals. ${ }^{6}$ While this desire to maintain purity suggests stasis rather than character development, Evelina is able to grow as a result of her education in social behaviour and, more specifically, public conversation. When Evelina first enters high society, she frequently experiences embarrassment which leaves her speechless, and her inability to express herself only compounds the anxiety of these social encounters. At her first ball, Evelina meets Orville and writes: "He seemed very desirous of entering into conversation with me; but I was seized with such a panic, that I could hardly speak a word." 7 During their second encounter that evening, Evelina's wordlessness becomes increasingly painful and she is "ready to sink with shame and distress" when Orville approaches: "I found it absolutely impossible to keep my seat, because I could not think of a word to say for myself, and so I rose, and walked hastily towards the card-room... He begged to know if I was not well? You may easily imagine how much I was embarrassed. I made no answer, but hung my head, like a fool, and looked on my fan." ${ }^{8}$ While Evelina is retrospectively aware of her social faux-pas, she lacks the necessary self-policing that forms an important part of politeness. Given her early behaviour in the novel, we would be excused for deeming

6. Evelina, 110.

7. Evelina, 122.

8. Evelina, 123. 
Evelina to be, as Orville does initially, "a silent [angel]... A poor weak girl!" if we did not have access to her well-written and observant letters. ${ }^{9}$ Frequently, Evelina's anxiety in unfamiliar social situations coupled with her lack of experience in polite speech prevent her from expressing or even defending herself. For instance, when Evelina recounts being trapped in a carriage with Sir Clement Willoughby, her discomfort is clear: "He drew me towards him as he spoke. I was frightened dreadfully, and could hardly say, 'No, Sir, no, - none at all, - only Mrs. Mirvan, - I think she will be uneasy'." ${ }^{10}$ Evelina's confused utterances ineffectively communicate her fear, and she is initially unsuccessful in her attempts to discourage Willoughby. ${ }^{11}$

If we read Evelina's growth as, in part, the development of her speech to equal the eloquence of her writing, then her confession scene with Villars at the end of volume two suggests a significant advance in her ability to express herself. Villars notices Evelina's depression after receiving Orville's offending letter, and he insists on conversing in order to initiate a confidence that will re-establish his relationship with his adopted daughter. Villars notices Evelina's discomfort and declares: "I can no longer be a silent witness of thy sorrow... it is painful to you to speak: suppose then, I endeavour to save you by guessing?"12 When Evelina does not respond, Villars places great importance on the power of willing communication: "How highly I value, how greatly I wish for her confidence... yet to extort, to tear it from her, - my justice, my affection, both revolt at the idea."13 Evelina replies, "Do you then refuse to hear me?" to which Villars responds, "No, but I abhor to compel you," and as Evelina breaks down she cries, "say then that you forgive me! that you pardon my reserve, - that you will again suffer me to tell you my most secret thoughts, and rely upon my promise never more to forfeit your confidence!"l4 In this moment of confession, Evelina admits to receiving Orville's incrimi-

9. Evelina, 128.

10. Evelina, 203.

11. See Susan Staves, who similarly observes that "when Evelina is alone in the coach with Sir Clement, he preserves his savoir faire while she is gradually reduced to stammering and speechlessness," in “Evelina': or, Female Difficulties," Modern Philology 73, no. 4.1 (1976): 371, http://www.jstor.org/ stable/435738.

12. Evelina, 394.

13. Evelina, 395.

14. Evelina, 395-96. 
nating letter, and Villars's suggestion that Orville might have written it while "intoxicated" allows Evelina to consider the possibility of exonerating Orville. ${ }^{15}$ For the first time in the novel, oral communication becomes more significant than letter-writing for the pair: Evelina's spoken (rather than written) confession helps repair the bond between Villars and his charge and provides a first step in demystifying the misattributed letter.

Over the course of the novel, Evelina becomes increasingly comfortable speaking in public, and by expressing herself politely and effectively she is increasingly understood. By the third volume, Evelina records articulate answers to Mrs. Beaumont's inquiries: "I declared myself very able to walk, and begged that I might accompany them."16 This response is confident and clear - the Evelina of volume one would have had difficulty "declar[ing]" herself, and the use of "begged" indicates conventional politeness - and since this exchange follows Lady Louisa's rude snubbing, it attests to both Evelina's composure and her growing ease at social speaking. Evelina's newfound awareness of appropriate conversation also enables her to express considerate responses that reflect her keen sensitivity; her insight, while evident in her letters, is now apparent in her speech as well. For instance, after Orville offers his phaeton to Evelina and Mrs. Selwyn, Evelina records her response: “'Indeed,' cried I, 'I had much rather walk. - ' But then, looking at Lord Orville, I perceived in his face a surprise so serious at my abrupt refusal, that I could not forbear adding 'for I should be sorry to occasion so much trouble."' ${ }^{17}$ Evelina is able to read the situation correctly and respond accordingly, and she notes the result: "Lord Orville brightening at these words, came forward, and pressed his offer in a manner not to be denied."18 Unlike their initial meeting, such instances of successful dialogue demonstrate Evelina's kindness and intelligence, and they help to bring her and Orville closer. Evelina's education in polite speech represents more than compliance to conventional means of expression: it becomes the process through which she can express herself and, by doing so, establish her agency in social situations.

15. Evelina, 398.

16. Evelina, 412.

17. Evelina, 414 .

18. Evelina, 414. 
Evelina's admiration for both Villars and Orville is grounded, in part, in appreciation of their language. Burney's characters reveal their true natures through their modes of speech, and Villars's and Orville's social politeness signifies their kindness, generosity, and consideration. In The Evolution of English Prose, Carey McIntosh discusses "the growth of politeness in the eighteenth century" and explains that "there were many more publications in grammar and rhetoric in the second half of the eighteenth century than in the first, and most of them exhibit a new form of language-consciousness, one that directly promotes the causes of politeness and literacy." 19 This culture of politeness values a delicate mode of speech which reflects consideration for others. Patricia Hamilton argues persuasively that "through Lord Orville, Burney endorses the system of polite behaviour that flourished in the first half of the eighteenth century," and she suggests that Orville embodies the early eighteenth-century ideal of the "well-bred gentleman" rather than that of the sentimental hero favoured later in the century. ${ }^{20}$ Hamilton and McIntosh recognize a similar model of politeness, but Hamilton locates its prominence in the earlier part of the century, whereas McIntosh contends that while "historians have located the emergence of politeness as a powerful cultural ideal in the years from about 1700 to 1720 ," his "reading suggests that this ideal did not change the way English was actually written until the 1750 os and 176os." ${ }^{21}$ In any event, politeness as a desirable social construct based on self-control and disciplined behaviour was well established by the time of Evelina's publication. It offered an alternative to the culture of sensibility, the "high value on naturalness" and spontaneity in the lateeighteenth century. ${ }^{22}$ As Evelina progresses in her narrative and masters polite discourse, her spontaneous reactions to society correspondingly give way to more self-controlled responses. Although this subscription to politeness might seem to obscure individual expression, it appears in the novel to allow for greater social agency and power. In Hypocrisy

19. Carey McIntosh, The Evolution of English Prose, 1700-180o: Style, Politeness, and Print Culture (Cambridge: CUP, 1998), 195, viii.

2o. Patricia L. Hamilton, "Monkey Business: Lord Orville and the Limits of Politeness in Frances Burney's Evelina," Eighteenth-Century Fiction 19.4 (2007): 417, doi: 10.1353/ecf.2007.0022.

21. McIntosh, Evolution of English Prose, ix.

22. Hamilton, 421. 
and the Politics of Politeness, Jenny Davidson argues "that the language of politeness offers a powerful alternative to the language of subjectivity for describing the various political and psychological concessions made by men and women in the quest for integration into and representation within linguistic, cultural and political communities." 23 In Evelina, polite discourse is a means of achieving social influence, while less well-spoken characters struggle to attain, or maintain, their prestige.

Although Villars employs polite language in his letters to encourage and reassure Evelina, his writing reaches only a private audience in his adopted daughter; Orville's polite speech in society, on the other hand, is more influential since it reaches a wider audience. For Evelina, Orville's politeness is an essential part of his appeal: "With what politeness did he address me! with what sweetness did he look at me! the very tone of his voice seemed flattering!" 24 Orville is a master of polite speech, and Evelina describes during the initial ball scene how his courtesy puts his listeners at ease and improves their conversation: "if my capacity, or even if my spirits had been better, in how animated a conversation might I have been engaged! It was then I saw that the rank of Lord Orville was his least recommendation, his understanding and his manners being far more distinguished." 25 This is the first of many scenes in which Orville distinguishes himself through his polite speech; Evelina, however, is unable to respond: "His remarks upon the company in general were so apt, so just, so lively, I am almost surprised myself that they did not re-animate me... Yet I had not the courage to attempt either to defend them, or to rally in my turn, but listened to him in silent embarrassment." ${ }^{26}$ However, politeness does not necessarily indicate sincerity. Davidson explores the potentially artificial aspect of acting politely in the eighteenth century when she notes that "manners - the social constraints that check the dictates of individual desire - represent a subtle but pervasive hypocrisy, a form of discipline that exacts certain penalties but also promises social and moral rewards." She acknowledges that while "self-control is never synonymous with hypocrisy... Johnson and Burney [demonstrate] a sincere wish to show

23. Jenny Davidson, Hypocrisy and the Politics of Politeness: Manners and Morals from Locke to Austen (Cambridge: CUP, 2004), 5.

24. Evelina, 413.

25. Evelina, 124.

26. Evelina, 124. 
that politeness and virtue are wholly compatible." 27 Certainly, Burney aligns "politeness and virtue" in Orville's character, whose inclusive and polite conversation suggests good breeding as well as a mild - and seemingly sanctioned - form of hypocrisy. Evelina notes that "whatever might be his doubts and suspicions, far from suffering them to influence his behaviour, he spoke, he looked, with the same politeness and attention with which he had always honoured me." 28 This passage illustrates how for Burney, Orville's polite speech - while perhaps hypocritical in its unwillingness to express "doubts and suspicions" - is nonetheless considerate and honourable.

Significantly, the eighteenth-century notion of polite language entailed complex gender connotations. Hamilton argues that early manuals and conduct-books on politeness participated in gender construction by delineating the role of the polite gentleman, ${ }^{29}$ and Davidson claims that the discourse of politeness was effectively appropriated by English women leading into the nineteenth century. ${ }^{30}$ McIntosh connects "politeness, the value most widely identified with 'high' culture in the eighteenth century" to "the new cultural vitality of women in the second half of that century. The 'feminization' of British culture had consequences not only for the novel and other genres but also for language and style." ${ }^{11}$ McIntosh argues that "the feminization of language and literature in the eighteenth century was noticed in the eighteenth century itself," 32 and in Evelina, Burney certainly associates politeness with femininity: while Mrs. Selwyn is portrayed as "masculine" because of her rude manners, Orville is often feminized by his politeness. ${ }^{33}$ Evelina describes how, "As a sister I loved him, - I could have entrusted him with every thought of my heart, had he deigned to wish my confidence; so steady did I think his honour, so feminine his delicacy, and so amiable his nature!" In particular, Orville's generosity of disposition suggests his feminine politeness to Evelina, who "imagine $[s]$ that the whole study of his life, and whole purport of

27. Davidson, 8.

28. Evelina, 365 .

29. Hamilton, 422-23.

30. Davidson, 11.

31. McIntosh, ix.

32. McIntosh, 196.

33. Evelina, 400. 
his reflections, tended solely to the good and happiness of others." 34 For Evelina, politeness is a generous and praiseworthy feminine attribute embodied in Villars and, to a greater extent, Orville. According to McIntosh, such gendered descriptors were not uncommon in the eighteenth century; he notes that "women are politer than men - or so the eighteenth century believed" and emphasizes that "the feminization of culture affected men as well as women.... Masculine values were articulated less often in a heroic and more often in a domestic frame." 35 The admirably "feminine" characteristic of politeness ensures that while Villars and Orville function as figures of male authority, their masculinity incorporates feminized models of polite speech to which Evelina can also gain access.

To further challenge the characterization of Villars and Orville as forces of masculine oppression, we must consider that while both men function as models of polite speech for Evelina to emulate so that she can learn to publicly express herself, they also acknowledge her intelligence, and - particularly in Villars's case - actively encourage her to exert agency. Orville recognizes that Evelina's “understanding is, indeed, excellent; but she is too young for suspicion, and has an artlessness of disposition that I never saw equalled." ${ }^{36}$ Appreciating Evelina's intelligence, he attributes her naiveté to her age and sincerity rather than her gender. Villars is even more explicit in his encouragement of Evelina. Despite his initial desire to retain her at Berry Hill for her protection (an understandable wish when we consider the fate of his two previous charges), Villars nonetheless encourages Evelina to think independently, and he asserts his confidence in her judgement and moral sense when he insists: "you must learn not only to judge but to act for yourself: If any schemes are started, any engagements made, which your understanding represents to you as improper, exert yourself resolutely in avoiding them, and do not, by a too passive facility, risk the censure of the world, or your own future regret." ${ }^{37}$ Clearly Villars admires Evelina and wants her to trust her instinct and judgement despite her youth and inexperience.

34. Evelina, 392.

35. McIntosh, 195, 207.

36. Evelina, 486.

37. Evelina, 279. 
Thus, although the novel endorses politeness, it does not identify politeness with passivity. Nowhere is the ratifying of personal agency more in evidence than when Evelina interrupts Mr. Macartney's suicide attempt through vocal interference and physical action. She exhorts: "O Sir! have mercy on yourself!" and when Macartney asks "What would you do?” Evelina recalls her answer: “Awaken you,' I cried, with a courage I now wonder at, "to worthier thoughts, and rescue you from perdition.' I then seized the pistols; he said not a word, - he made no effort to stop me." 38 Macartney's passive silence in the face of Evelina's succinct assertion of her purpose suggests his submission to her will. Villars's response in turn reinforces her agency. Far from discouraging such a risky intervention on Evelina's part, he commends her courage: "Be ever thus, my dearest Evelina, dauntless in the cause of distress! let no weak fears, no timid doubts, deter you from the exertion of your duty, according to the fullest sense of it that Nature has implanted in your mind." Villars insists that "fortitude and firmness, when occasion demands them, are virtues as noble and as becoming in women as in men: the right line of conduct is the same for both sexes," and he truly encourages Evelina's autonomy so that she can do greater good. ${ }^{39}$ While Villars and Orville certainly conform to polite standards and, by example, encourage Evelina to do the same, their genteel social code does not entail female submission. Rather, Evelina's development in public speech allows her to express herself, and her guiding male influences - Villars and Orville - encourage her forthrightness.

Although Burney endorses Villars and Orville as exemplary figures for Evelina, she also provides several foils as contrast. Mr. Lovel, Lord Merton, and Sir Clement Willoughby offer particularly interesting negative models of male speech since their affectations contrast deliberately with the polite accommodating style of Orville, the man with whom they converse easily in social situations. After Evelina unwittingly embarrasses Lovel by laughing at his advances, he attempts to humiliate her at the theatre: "He spoke with a self-complacency that convinced me he had studied this address, by way of making reprisals for my conduct at the ball." ${ }^{\prime 0}$ Lovel speaks "in an easy, negligent way"

38. Evelina, 300-01.

39. Evelina, 341.

40. Evelina, 179. 
and implies that Evelina is ill-suited to society: "Our customs, our manners, and les etiquettes de nous autres, can have very little resemblance to those you have been used to. I imagine, Ma'am, your retirement is at no very small distance from the capital?" Evelina remembers being "so much disconcerted at this sneering speech, that I said not a word; though I have since thought my vexation both stimulated and delighted him." ${ }^{41}$ However, when suddenly confronted by the Captain, Lovel, without the aid of his rehearsed dialogue, disintegrates into stammering nonsense: "Why, really, Sir, a play requires so much attention, - it is scarce possible to keep awake, if one listens... But, now I think of it, I believe I have a bill in my pocket; $\mathrm{O}$, ay, here it is - Love for Love, ay, - true, - ha, ha, - how could I be so stupid!" 42 Merton, "a nobleman who is but lately come to his title, though he has already dissipated more than half his fortune," while slightly less ridiculous than Lovel, speaks in a similarly affected manner which, for Burney, indicates his reputation: he is "a man of most licentious character... among men, his companions consisted chiefly of gamblers and jockies, and among women, he was rarely admitted." ${ }^{43}$ Interestingly, Merton insists that women have no business speaking "sense" since "a woman wants nothing to recommend her but beauty and good-nature; in every thing else she is either impertinent or unnatural. For my part, deuce take me if ever I wish to hear a word of sense from a woman as long as I live!" ${ }^{44}$ Lovel and Merton's language and opinions on feminine speech are in sharp contrast to Orville's, a difference observed by Evelina when, "in the midst of this trifling conversation, Lord Orville made his appearance. O how different was his address! How superior did he look and move, to all about him!"45 As we have seen, Orville (like Villars) is open to and encouraging of female conversation, and he speaks with an exemplary politeness; correspondingly, the men with impolite speech - often marked by neologism, profanity, and affectation - in Evelina are generally inferior characters with negative views on female discourse and intelligence.

41. Evelina, 180.

42. Evelina, 182.

43. Evelina, 407.

44. Evelina, 504.

45. Evelina, 418. 
The specifics of Sir Clement Willoughby's negative speech are more fully developed than those of Lovel or Merton. In his attempts to woo Evelina, Willoughby employs theatrical chivalric discourse, as in the carriage scene when he calls her "my dearest life" and asks, "is it possible you can be so cruel? Can your nature and your countenance be so totally opposite? Can the sweet bloom upon those charming cheeks, which appears as much the result of good-humour as of beauty - " before Evelina "interrupt[s] him," stating, "this is very fine; but I had hoped we had had enough of this sort of conversation at the Ridotto." ${ }^{46}$ Evelina has little patience for this exaggerated chivalric discourse; moreover, she recognizes the apparent hypocrisy of Willoughby insistently playing the role of a devoted lover while continuing to harass her. In the carriage, she remembers: "Never, in my whole life, have I been so terrified." ${ }^{47}$

Evelina explicitly addresses Willoughby's hypocrisy in the third volume when he claims, "I almost suffered martyrdom for the pleasure of seeing you... Yes, beauteous insensible! martyrdom: for did I not compel myself to be immured in a carriage, the tedious length of a whole morning, with the three most fatiguing women in England?"48 Evelina is shocked at this insult since Willoughby has acted as a favourite of Mrs. Beaumont, Mrs. Selwyn, and Lady Louisa. She admonishes him, "How little... are those Ladies aware of such severity from you!"; she is "quite amazed... that, with such opinions, you can behave to them all with so much attention and civility." ${ }^{49}$ Through Willoughby, Burney addresses the threat of hypocrisy buried in polite speech which is the focus of Davidson's study. However, Willoughby's hypocrisy exceeds the bounds of politeness since he curries favour while blatantly contradicting his earlier performance of politeness. Burney in effect nullifies the threat of hypocrisy in polite speech by making it so easily detectable: hypocritical speech is derivative as it relies in studied ways on extrinsic models, whether those have been mastered (as with Willoughby) or need to be prepared in advance (as with Lovel). Orville's polite speech, by contrast, has an ease and transparency that grows naturally out of his own inherent sociability. Furthermore,

46. Evelina, $2 \mathrm{O}$.

47. Evelina, 203.

48. Evelina, 481.

49. Evelina, 482-83. 
Willoughby, like Merton, endorses the double standard of female speech: he criticizes Mrs. Selwyn for "the unbounded licence of her tongue," and when Evelina ironically inquires, "O Sir Clement, do you object to that?" he replies: "Yes, my sweet reproacher, in a woman, I do; in a woman I think it intolerable." ${ }^{50}$ Once more, a questionable male character associated with improper speech rejects the value of female oration. While Evelina and Orville also believe that Mrs. Selwyn crosses the bounds of acceptability, the objection, as Evelina implies, is to Willoughby's assumption that he can be unlicensed while she cannot.

Rude and ineffective language can compromise the authority and reputation of both men and women in Evelina, and the novel presents many instances in which older women and their speech are proposed as possible models for the young Evelina. Burney focuses little on Evelina's peers - Miss Mirvan is remarkably silent, the Branghton girls are silly, and Lady Louisa speaks "with an air of languor" and "a most affected voice" which leads Evelina to compare "the unexpected politeness of Lord Orville" to "the contemptuous failure of it in his sister" - and instead concentrates on the relation between speech and reputation in her older female characters. ${ }^{51}$ Specifically, each of the three women who dominate the novel's three locales - Lady Howard, Madame Duval, and Mrs. Selwyn - is defined by a distinct mode of speaking that reflects her status. Both Madame Duval and Mrs. Selwyn speak rudely and, consequently, appear less admirable and communicate less effectively than polite speakers: Madame Duval's vulgar, illiterate, and heavily accented mode of expression is mocked throughout the novel, and Mrs. Selwyn's brash, overly censorious style intimidates rather than improves less intelligent characters. Lady Howard, on the other hand, embodies the advantages and reformative agency associated with polite speech.

The reader is introduced to Madame Duval when Lady Howard receives a letter from her and writes to Villars: "The chief purport of her writing I will acquaint you with; the letter itself is not worthy your notice." 52 As is the case with other characters in Evelina, one's speech

50. Evelina, 482.

51. Evelina, 410, 419.

52. Evelina, 99. 
and writing reflects one's disposition; evidently, Madame Duval's letter indicates her lamentable character and speech. We never read Madame Duval's writing - her voice is always filtered through Evelina's letters - but Lady Howard is disparaging when she notes, "it is evident, from her writing, that she is still as vulgar and illiterate as when her first husband, Mr. Evelyn, had the weakness to marry her; nor does she at all apologise for addressing herself to me, though I was only once in her company." ${ }^{33}$ This early passage establishes important associations between class, reputation, and status and literacy, writing skills, and proper forms of address that confirm McIntosh's claim that in the eighteenth century, "loose, informal, and colloquial prose came under heavy fire in the prescriptive grammars" as "the rising middle class in this period aspired fervently to correctness and politeness." ${ }^{54}$ Madame Duval's spoken language echoes her writing: Evelina notes that "the continual wrangling and ill-breeding of Captain Mirvan and Madame Duval, made me blush that I belonged to them," and she expresses "concern" and "indignation" when she learns "that Madame Duval was entertaining Mr. Branghton with all the most secret and cruel particulars of my situation!"55 Madame Duval's improper behaviour is paralleled in her inappropriate, falsely accented, and ungrammatical speech. Her language denotes her class position, and despite her attempts to seem genteel, her insistence on her status in France seems showy and pathetic; it is clear to her listeners (and the reader) that she has been entirely unsuccessful in her attempts to conceal her low English birth by affecting a French accent and continental origin. If politeness reins in spontaneity for a greater social good, Madame Duval reveals that a lack of self-control - or an excess of impulsive speech - reflects an inconsistent, emotional, and difficult character.

Like Willoughby, Mrs. Selwyn is linked with a distinct mode of speech: Evelina introduces her by noting "her unmerciful propensity to satire. ${ }^{" 56}$ Mrs. Selwyn is aggressively critical, and while her judgements are presumably aligned with Burney's (her most frequent targets are Lovel and Merton), her vehement delivery is unsettling and problematic: "her understanding, indeed, may be called masculine;

53. Evelina, 100.

54. McIntosh, 28.

55. Evelina, 155, 168.

56. Evelina, 400. 
but, unfortunately, her manners deserve the same epithet." ${ }^{157}$ Evelina observes Mrs. Selwyn "looking round her with the utmost contempt" and wonders, "how many enemies... does this unbounded severity excite!" while Willoughby notes that she "spreads a general uneasiness among all who are in her presence; and she talks so much, that even the best things she says, weary the attention." ${ }^{58}$ Unsurprisingly, given her satiric propensity, Mrs. Selwyn is political: she habituates "a pamphlet-shop," and her critiques extend beyond the individual to encompass political factions when she mocks the political aspirations of Lord Merton and Mr. Lovel, who are members of the House of Lords and the House of Commons, respectively. ${ }^{59}$ John Brewer suggests that "the aim of politeness was to reach an accommodation with the complexities of modern life and to replace political zeal and religious bigotry with mutual tolerance and understanding." ${ }^{60}$ Far from contributing to "mutual tolerance," Mrs. Selwyn discourages others from engaging in conversation since her satiric speech simply mocks weakness instead of offering a means for improvement. The problem with Mrs. Selwyn's speech lies, then, not in her understanding but in her delivery: her abrasive and inflammatory language upsets rather than informs her listeners. While her insights may be accurate, without the palliating force of polite language, they are neither effective nor instructive.

Although there are few positive female examples of politeness for Evelina, Lady Howard seems at once to exemplify and to recognize the potential consequences of successful social behavior. Arguably the most respectable and socially powerful woman in the novel, Lady Howard reveals her mastery of polite social discourse through her letters; she is also the character who convinces Villars that Evelina must continue her social education in an effort to secure the recognition of her true father and hence allow for better marriage opportunities. Lady Howard contends that Evelina should not remain hidden from society as she "has merit which ought not to be buried in obscurity" and "seems born for an ornament to the world. ... I cannot but think, that

57. Evelina, 400.

58. Evelina, 504, 482-83.

59. Evelina, 455, 503 .

6o. John Brewer, The Pleasures of the Imagination: English Culture in the Eighteenth Century (New York: Farrar, Straus \& Giroux, 1997), 102. 
it was never designed, for one who seems meant to grace the world, to have her life devoted to retirement." ${ }^{\text {"Il }}$ Understanding that a socially prominent marriage will give Evelina a degree of social and even philanthropic agency, Lady Howard adds, "To despise riches, may, indeed, be philosophic, but to dispense them worthily, must surely be more beneficial to mankind." ${ }^{2}$ Lady Howard is herself a standing lesson in the efficacy of social discourse: her letters politely and subtly sway Villars, she reads and dismisses Madame Duval's language with facility, and she delicately avoids the Captain in order to evade his unpleasantness without making her daughter uncomfortable. As Davidson notes, "it is clear enough that manners are all about power,"63 and through Lady Howard, we can appreciate the social benefits of polite behaviour and language for a young woman like Evelina. Indeed, Lady Howard's purpose in campaigning for Evelina's place in society is to allow her the marriage opportunities which will best afford her social agency.

In order for Evelina to achieve this influence, she must make a double transition, not only in topographical terms from Berry Hill to the wider social realms of Howard Grove and London, but also in linguistic terms from private epistolary correspondence to public speech. Brewer acknowledges the eighteenth-century belief that "politeness... could not flourish in isolation. It would wither into selfregard or mutate into intolerance unless it was cultivated in society. It thrived on being watched and seen." ${ }^{64}$ By remaining at Berry Hill, Evelina would not only have insufficient social and philanthropic opportunity, she would also have limited means of developing her education in politeness since "the home of politeness was in company, and the place of company was in the institutions that lay at the heart of urban culture." ${ }^{65}$ Evelina's marriage, then, symbolizes not just the fruition of her social education; it also promises the future development of her polite discourse along with social agency. As the novel's most polite character, Orville embodies the effectiveness of using considerate speech in order to convey personal virtue to the public.

61. Evelina, 231-32.

62. Evelina, 232.

63. Davidson, 10.

64. Brewer, 102.

65. Brewer, 103. 
The concluding marriage and the end of Evelina's letter-writing do not necessarily symbolize the reinstatement of patriarchal authority; rather, they mark Evelina's shift from one mode of communication in her private life to another in the public sphere. While Evelina's virtue, intelligence, and eloquence are apparent to the reader through her letters, her command of public speech enables her to influence others by her example and, presumably, to improve others and society with her benevolence. For Burney, the social attitude of politeness is not merely a form: it is the means through which a woman can gain respect, agency, and the ability to express herself upon "her entrance into the world." 